\title{
Development of Bacterial Consortia for Solid Waste Degradation and its Use as Organic Manure
}

\author{
Suparna Deepak", Shamshad Ather" and Omkar Koppaka ${ }^{*}$ \\ Department of Biotechnology, Pillai College of Arts, Commerce and Science, New Panvel, Navi Mumbai, Maharashtra, India \\ \# Both the authors have equal contributions
}

"Corresponding author: suparnadeepak@mes.ac.in (ORCID ID: 0000-0001-7427-0845)

Paper No. 863

Received: $18-08-2020$

Revised: $17-11-2020$

Accepted: 05-12-2020

\begin{abstract}
Solid waste disposal has become a big concern all over the world. Almost $50 \%$ of the municipal waste collected daily, especially in the metropolitan cities where the population is very high, consists of organic solid waste. This organic waste left in the open dumping grounds results in stench and contamination of groundwater. The present study aims to find out the utilization of effective microbial consortia for decomposing the organic waste. Different garbage samples was collected from Panvel area for isolating the effective organic waste degrading organisms. These strains were characterized by microscopic observations and biochemical tests. Their cellulolytic, proteolytic, amylolytic and lipoolytic activities were evaluated. Depending on these enzyme activities, different consortia were prepared and their efficacy in reduction, maturity and deodorization of organic waste was compared. The plant growth promoting effect of this degraded waste on Triticum aestivum (wheat) and Zea mays (maize) was evaluated. 5 Different Microbial Consortium was developed. Microbial consortia increased the efficacy of composting as compared to control. Consortia no. 1 and 5 showed better degrading ability. Consortia 4 and 5 facilitated the best growth for Wheat and Maize respectively. Consortia 2 showed the best result in terms of germination and growth for both wheat and maize.

\section{Highlights}

( All the groups of consortia were effective in terms of degradation of MSW, improving the properties of soil and growth of the plants

( Also, when comparing with the control, the phosphorus, nitrogen content and plant growth showed great improvements
\end{abstract}

Keywords: Compost, effective microbes, wheat, maize, degradation, solid waste management

Solid waste in this age has proved to be one of the more concerning issues in India as well as the world (Rakshit et al. 2018). Solid waste refers to any garbage in solid or semisolid state that are derived and discarded from all over the local area and is also called municipal solid waste (MSW). India is one of the largest countries in the world in terms of area and population. With an exponential increase in population each year, generation of MSW has also increased. This has led to an increase in MSW in such proportions that area for disposal is starting to become an issue (Gupta et al. 1998). Improper disposal of MSW causes various health issues and depend upon the location, type of waste and the duration of exposure (Ziraba et al. 2016). Landfilling, open dumping and composting are some of the current methods used to dispose of MSW (Joshi et al. 2016). Each of these methods come with their own disadvantages. Among the waste generated in India, $40-60 \%$ is compostable (Joshi et al. 2016). With India being the largest producer of fruits and second largest producer of vegetables

How to cite this article: Suparna, D., Ather, S. and Koppaka, O. 2020. Development of Bacterial Consortia for Solid Waste Degradation and its Use as Organic Manure. IJAEB, 13(4): 415-422.

Source of Support: None; Conflict of Interest: None 
in the world, food wastes form a large part of the afore mentioned compostable wastes (Singh et al. 2016). These food wastes contain components that are easily degradable including sugars, fats, starches, proteins, etc. (Song et al. 2018). All the food waste is also disposed in open dumps and landfils which require large amounts of space, cause leachates to permeate into the soil and thus into the groundwater and release compounds that create unpleasant odour and attract mosquitoes, cockroaches and rodents, thus playing a major role in spread of diseases. Composting is a sustainable option, but without any intervention, it takes a lot of time. Also, the stench released during composting also pose many threats to health and environment. This tends to become a major problem especially during the summers (Kumar et al. 2017). However, microorganisms contain the enzymes necessary to degrade these substances. The objective of this study is to capitalize on these properties of microorganisms to design a consortium that could hasten the degradation of organic wastes without emanating any odor during composting and to study its effect on the growth of the plants and the quality of soil.

\section{MATERIALS AND METHODS}

\section{Development of Consortia}

\section{Sample Preparation}

Samples were collected from decaying garbage of Pillai College's canteen garbage pit. All the samples were mixed and suspended in $1000 \mathrm{ml}$ of sterile distilled water and then the solid matters were removed using Sterile forceps. The suspension was shaken vigorously and $10 \mathrm{ml}$ of remaining suspension were serially diluted (Under Aseptic Condition) up to $10^{-7}$ by adding the $10 \mathrm{ml}$ suspension in $90 \mathrm{ml}$ of Sterile physiological saline then $1 \mathrm{ml}$ of diluted sample was mixed in a sterile test tube with $9 \mathrm{ml}$ of sterile physiological saline, same steps were carried out till the last dilution factor reached to $10^{7}$. The last 4 dilutions were used for isolation of micro-organisms.

\section{Isolation}

Diluted samples $10^{-4} 10^{-5} 10^{-6}$ and $10^{-7}$ were inoculated on separate Sterile Nutrient Agar plates at room temperature for $24 \mathrm{hrs}$. Colony characteristics (color, margin, opacity, size, elevation, consistency) and gram nature as well as sporulation was studied. 12 colonies with distinct features (colony characteristics) were streaked on Sterile NA plates and reintubated for $24 \mathrm{hrs}$ at room temperature for further studies. After incubation each colony were streaked on four different set of media plates designed to check the enzymatic (Proteolytic, Cellulolytic, Lipolytic and Amylolytic) actions of microbes.

\section{Enzyme Assays}

For proteolytic assay organisms were inoculated in skim milk agar (1\%) (Dalal 2015). The media used for isolation of cellulolytic (Muhammad I, et.al, 2012) bacteria contains $1.0 \%$ peptone, $1.0 \%$ carboxymethylcellulose (CMC), $0.2 \% \mathrm{~K}_{2} \mathrm{HPO}_{4^{\prime}} 1 \%$ agar, $0.03 \% \mathrm{MgSO}_{4} .7 \mathrm{H}_{2} \mathrm{O}, 0.25 \%\left(\mathrm{NH}_{4}\right)_{2} \mathrm{SO}_{4}$ and $0.2 \%$ gelatin at $\mathrm{pH} 7$ for 48 hours of incubation at $30^{\circ} \mathrm{C}$. Lipolytic activity (Veeranna et al. 2012) was studied using media with $0.5 \%$ Peptone, $1 \%$ tributyrin, $0.3 \%$ yeast extract, $2 \%$ agar, $0.5 \% \mathrm{NaCl}$. Whereas Amylolytic (Sharma et al. 2015) microbes were observed on peptone $0.5 \%$, beef extract $0.3 \%$, soluble starch $0.2 \%$, agar $1.5 \%$. After incubation of $48 \mathrm{hrs}$ at room temperature plates for cellulolytic and amylolytic were flooded with congo-red and iodine solution respectively and the zone of color change was noted.

The isolates were inoculated and incubated in Sterile NA slants for $24 \mathrm{hrs}$ and stored at $4^{\circ} \mathrm{C}$ for further studies.

\section{Biochemical Tests}

Physiological Saline suspension of each isolates were prepared for inoculation purposes.

Catalase Test (Tankeshwar 2019): A loop full culture of isolates were mixed with 2-3 drops of Hydrogen Peroxide.

Urease Test: $5 \mathrm{ml}$ of Christensen Urea broth (Peptone $0.1 \%$, Dextrose $0.1 \%, \mathrm{NaCl} 0.5 \%$, Disodium phosphate $0.12 \%$ Monopotassium phosphate $0.08 \%$, Phenol red $0.012 \%$, Final $\mathrm{pH}\left(\right.$ at- $\left.25^{\circ} \mathrm{C}\right) 6.8 \pm 0.2$ ) was inoculated with $0.1 \mathrm{ml}$ of culture suspension and incubated for $24 \mathrm{hrs}$ at Room Temperature.

IMViC Test: Test was performed as described by Zaved et al. (2008). 
TSI Test: Procedure was followed as mentioned at microbeonline website (Tankeshwar 2019).

\section{Consortia Preparation}

After isolation and studying the enzymatic activity of isolates, 5 different consortia was prepared based on their enzyme efficacy.

\begin{tabular}{ll}
\hline Consortium & Isolates No. \\
\hline 1 & All \\
2 & $1,6,8$ \\
3 & $6,9,10,12$ \\
4 & 3,8 \\
5 & 2,10 \\
\hline
\end{tabular}

$1 \mathrm{ml}$ of each isolates were added in to $100 \mathrm{ml}$ of Nutrient Broth of respective consortia. The inoculated NB flasks were incubated for $24 \mathrm{hrs}$ at room temperature.

6 pots were marked and set to mimic compost pit out of which, 1 pot was set as control. Equal amounts of Solid Kitchen Wastes were added in to pots at the interval of 3 days along with $10 \mathrm{ml}$ of consortia without turning/disturbing the earlier batch. The control pot's wastes were allowed to degrade under the influence of aerobiota.

The consistency and odour of each pot were examined before addition of new batch. The degradation was checked till $16^{\text {th }}$ day. Till now each pot were fed up-to 5 batches and results were very promising.

\section{Effect of Compost on the Soil Properties}

\section{Determination of organic Carbon $(\mathrm{OC})$ and Organic Matter (OM) of control and fertilizer applied soils}

The organic carbon content in the soil samples were determined by Walkley-Black acid digestion method (Walkley et al. 1934). $1 \mathrm{~g}$ of $0.2 \mathrm{~mm}$ soil sample was added in $500 \mathrm{~mL}$ conical flask to which $10 \mathrm{~mL}$ of Potassium dichromate and $20 \mathrm{~mL}$ Sulphuric acid was added. The mixtures was gently mixed and incubated for 30 mins for the reaction to complete. The reaction mixture was further diluted with 200 $\mathrm{mL}$ distilled water and $10 \mathrm{~mL}$ orthophosphoric acid was added. $1 \mathrm{~mL}$ diphenylamine indicator was added and the solution was titrated with $0.5 \mathrm{M}$ ferrous ammonium sulphate solution to a brilliant green colour. A blank without soil was run simultaneously.

Organic carbon $\%$ in soil $=(X-Y) \mathrm{ml} \times 0.003 \times 100$ $\div 2 \times W=Z$

Organic carbon $\%$ in soil $=Z \times 1.3=R$

Where, $X=$ blank titration reading; $Y=$ sample reading; $W=$ Weight of soil used

Organic matter in soil $(\%)=R \times 1.724$

\section{Determination of Nitrogen of control and fertilizer treated soil samples}

Determination of available nitrogen in soil was done by Alkaline potassium permanganate method (Subbiah et al. 1956). $20 \mathrm{~g}$ of soil was transferred in a distillation flask. $20 \mathrm{ml}$ water and $100 \mathrm{ml}$ of 0.32 per cent $\mathrm{KMnO}_{4}$ solution was added. $20 \mathrm{ml}$ of 0.02 $\mathrm{N} \mathrm{H}_{2} \mathrm{SO}_{4}$ was added in a $250 \mathrm{ml}$ conical flask and two or three drops of methyl red indicator was added. The flask was put below the receiver tube. $100 \mathrm{ml} 0.32 \% \mathrm{KmnO}_{4}$ and $100 \mathrm{ml}$ of $2.5 \% \mathrm{NaOH}$ was added to the distillation flask containing soil and immediately connected the flask with the distillation apparatus. The distillation flask was heated. The distillation was continued till the evolution of ammonia from distillation flask took place; which was tested by bringing a moist red litmus paper near the outlet of condenser, which turned blue as long as ammonia was being evolved. No change in red litmus paper showed the completion of the ammonia distillation. The excess of $\mathrm{H}_{2} \mathrm{SO}_{4}$ was titrated with $\mathrm{N} / 50 \mathrm{NaOH}$.

Per cent available nitrogen $=(X-Y) \times 0.00028 \times$ $100 / 20$

Where, $X=$ Volume of $\mathrm{N} / 50 \mathrm{H}_{2} \mathrm{SO}_{4}$ taken; $Y=$ Volume of $\mathrm{N} \backslash 50 \mathrm{NaOH}$ used

Available nitrogen in $\mathrm{ppm}=$ percent $N \times 10^{4}$

\section{Determination of Phosphate of control and fertilizer treated soil samples.}

Soil phosphorous available for plants is determined by using Olsen's method of extraction with $\mathrm{NaHCO}_{3}$ (Olsen et al. 1954). The standard curve of different concentrations of $\mathrm{P}, 0.04,0.08,0.12,0.16,0.20$, $0.24,0.28,0.32,0.36$ and 0.40 ppm $\mathrm{P}$, respectively was prepared using 100 ppm $\mathrm{KH}_{2} \mathrm{PO}_{4}$ solution. Also a blank was prepared without adding $\mathrm{KH}_{2} \mathrm{PO}_{4}$ solution. The readings were taken on 
spectrophotometer at $660 \mathrm{~nm}$. The curve is plotted taking the spectrophotometer reading on vertical axis and amount of P in ppm on horizontal axis.

$2.5 \mathrm{gm}$ of air dried soil was taken to which $50 \mathrm{~mL}$ of the Olsen extracting solution $\left(0.5 \mathrm{M} \mathrm{NaHCO}_{3}\right.$ with $\mathrm{pH}$ adjusted to 8.5 using $1 \mathrm{M} \mathrm{NaOH})$. The beaker was placed on a magnetic stirrer and stirred gently for 30 minutes. The mixture was filtered. $5 \mathrm{ml}$ of the filterate was taken in a $25 \mathrm{ml}$ volumetric flask and $5 \mathrm{ml}$ of ammonium molybdate solution and $1 \mathrm{ml}$ of $\mathrm{SnCl}_{2}$ solution was added and the volume was made upto $25 \mathrm{ml}$ with distilled water. Reading were taken at $660 \mathrm{~nm}$ in a spectrophotometer.

Available $P(\mathrm{ppm})=(\mathrm{ppm} P$ obtained from graph by using soil sample - ppm P obtained from graph by using blank sample) $\times 100$ ( d.f.)

\section{Effect of Consortia on Plant Growth}

14 pots were set to study the effect of the manure produced by the degradation of kitchen waste by the different consortia. 200 gms of garden soil was added in all the pots, 50 gms of manures from earlier pots were mixed with garden soils and a new garden soil control was established to check usual effect of garden soil on maize and wheat growth. 2 sets of 7 pots (i.e. Soil Control, Consortia Control and Consortia 1-5) were set up.

Seeds of wheat and maize were soaked overnight. Next day each pot from one set was sowed with 10 seeds of wheat and the other set were sowed with maize. Pots were irrigated with $20 \mathrm{ml}$ of tap water at interval of a day. The germination rate was calculated. After a week medium sized plants from each pots were uprooted and the shoot as well as root length were measured.

\section{RESULTS AND DISCUSSION}

\section{Characterization}

The organisms were isolated on their respective media as discussed earlier. Standard characterization protocols were performed for identification of the organisms.

\section{Enzymatic activities evaluation}

Enzymatic activities were evaluated using different media specific for lipase, protease, cellulose and amylase.

\section{Consortia formation}

It has been verified via earlier studies that a group of microorganisms show better activity synergistically than their individual counterparts (Sarkar et al. 2017). This group of microbes that represent a sum of their activities showing better results is known as a consortia. Different consortia of organisms were organized on the basis of the potency of their enzymatic activities.

\section{Degradation of waste}

Composting takes as long as 3 months for complete degradation depending on the conditions without any added assistance (USEPA, 2017). As can be observed from Fig. $X$ and $Y$, the composting using the consortia is more efficient as compared to the conventional methods. Different types of fruit and vegetable wastes showed variation in the time taken for their degradation depending upon their complexity and hardness. Therefore, a control devoid of any consortia was set up and was used to compare the efficacy of composting using the consortia. In terms of rate of degradation, consortia 1 and 5 showed quicker degradation followed by consortia 4, 2, 3 and the control respectively. Consortia 1, 2, 4, 5 show the most efficient degradation (complete degradation into a paste like consistency after day 16) while Consortia 3 and the control show the least efficiency as depicted in the graph (Graph 1). Notably, there was no foul gas production in all the pots set up for composting using different consortia of microbes as compared to the control pots which were allowed to decompose on its own.

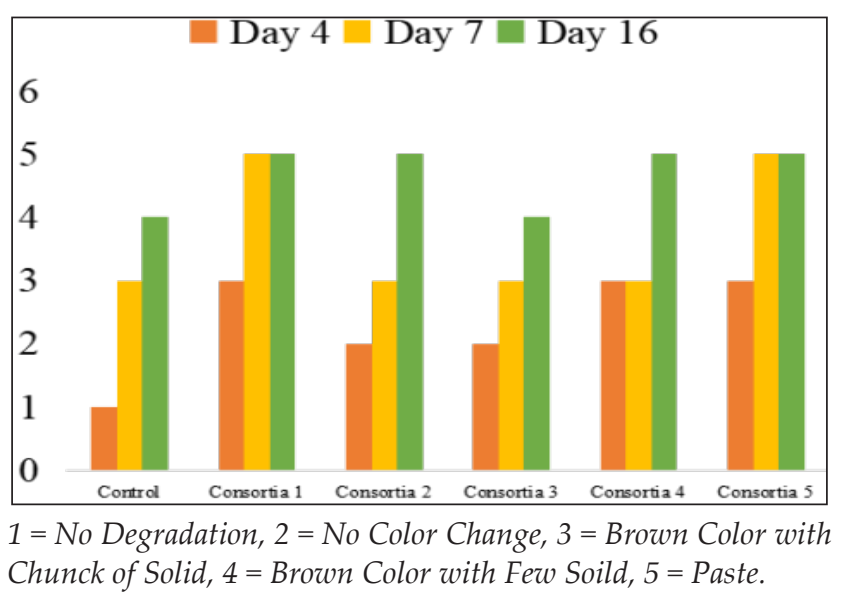

Graph 1: Graphical representation degradation of kitchen waste by different consortium 
Table 1: Biochemical Characterization

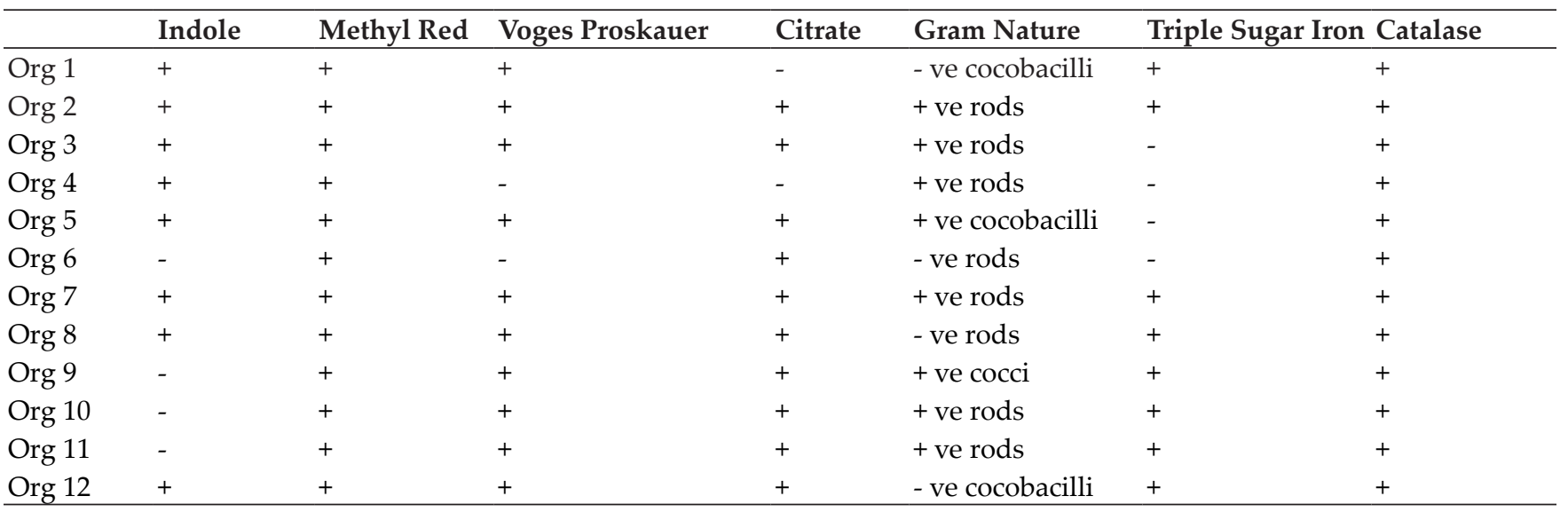

Key: + ve positive, - ve negative.

Table 2: Enzymatic Activities of the Isolates

\begin{tabular}{|c|c|c|c|c|}
\hline & LIPASE & PROTEASE & CELLULASE & AMYLASE \\
\hline$\overline{\text { Org } 1}$ & + ve & + ve & - ve & + ve \\
\hline Org 2 & + ve & + ve & + ve & - ve \\
\hline Org 3 & + ve & - ve & - ve & + ve \\
\hline Org 4 & + ve & - ve & - ve & + ve \\
\hline Org 5 & + ve & - ve & - ve & - ve \\
\hline Org 6 & + ve & + ve & - ve & + ve \\
\hline Org 7 & + ve & - ve & - ve & - ve \\
\hline Org 8 & + ve & + ve & + ve & - ve \\
\hline Org 9 & + ve & - ve & + ve & - ve \\
\hline Org 10 & + ve & - ve & - ve & + ve \\
\hline Org 11 & + ve & + ve & - ve & - ve \\
\hline Org 12 & + ve & - ve & - ve & - ve \\
\hline
\end{tabular}

Key: + ve positive, - ve negative.

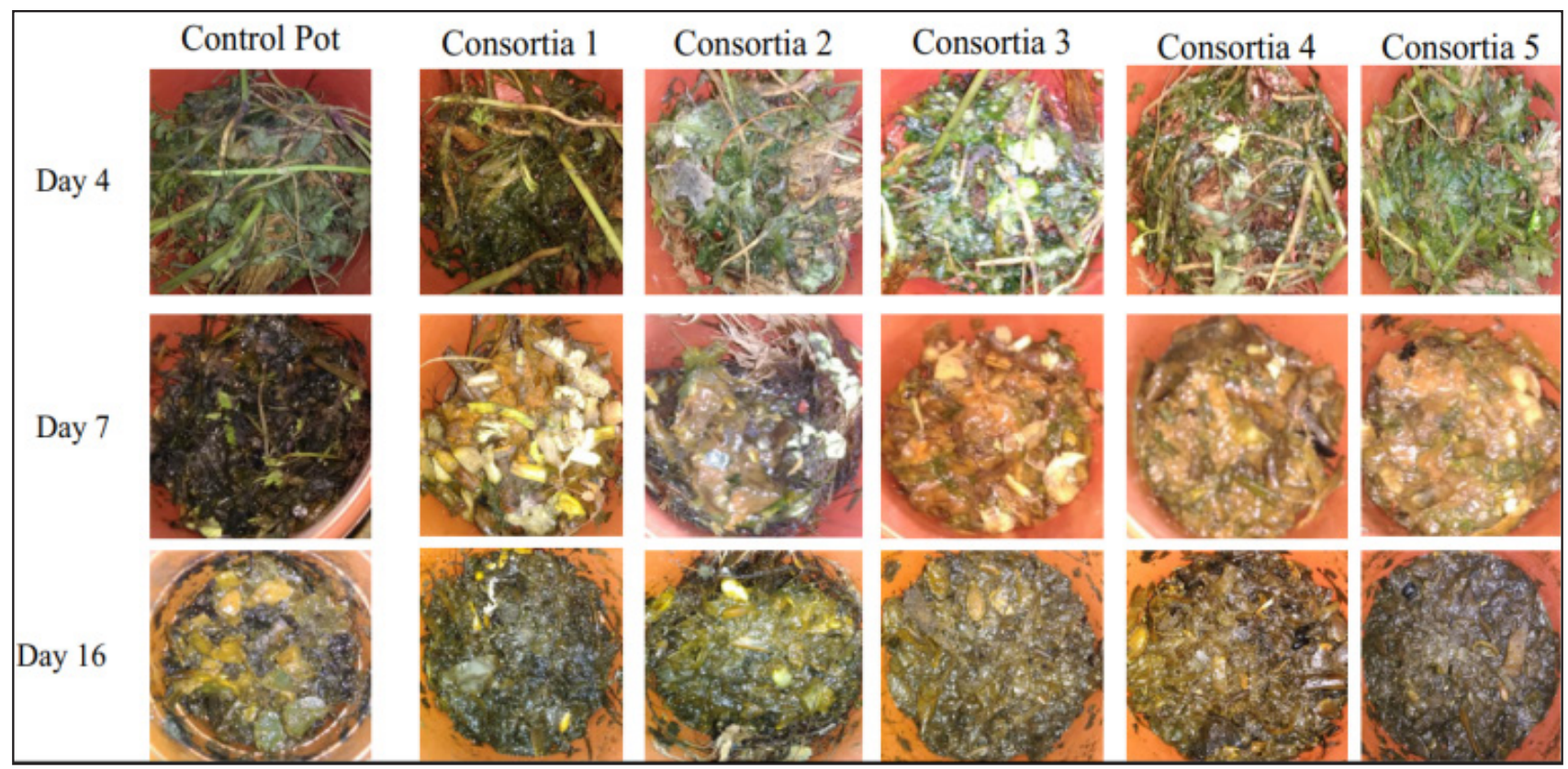

Fig. 1: Degradation of kitchen waste by different consortia 


\section{Effect of Compost on Soil Quality}

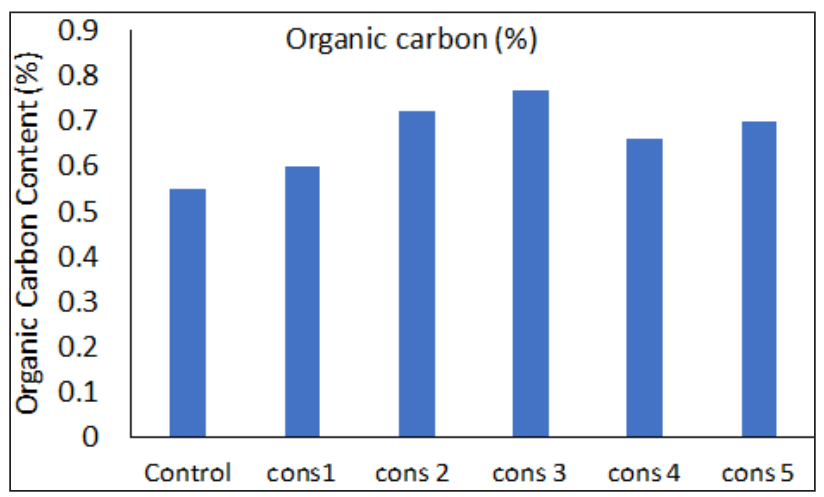

Graph 2: Effect of compost on organic carbon content (\%) of soil

The organic carbon and nitrogen level was increased in soil after the addition of the compost. This increase may because of release of nitrogenous content and carbon compounds on degradation of organic waste. As per the rating given by Olsen, the control soil contained medium level of phosphorus which was found to be increased with the addition of the compost and in case of consortium 4, the addition of the compost increased the phosphorus level to high (Horneck et al).

Table 3: Effect of Compost on Nitrogen and Phosphorus content of soil

\begin{tabular}{|c|c|c|c|c|c|c|}
\hline \multirow{2}{*}{ Criteria } & \multirow{2}{*}{ Cont } & \multicolumn{5}{|c|}{ Soil with the compost } \\
\hline & & $\mathrm{C} 1$ & $\mathrm{C} 2$ & $\mathrm{C} 3$ & $\mathrm{C} 4$ & $\mathrm{C} 5$ \\
\hline Organic Matter (\%) & 0.9 & 1.0 & 1.1 & 1.2 & 1.1 & 1.2 \\
\hline $\begin{array}{l}\text { Available Nitrogen } \\
\text { (ppm) }\end{array}$ & 74 & 112 & 110 & 115 & 135 & 134 \\
\hline $\begin{array}{l}\text { Available phosphorus } \\
(\mathrm{ppm})\end{array}$ & 12 & 15 & 12 & 17 & 28 & 23 \\
\hline
\end{tabular}

\section{Effect of compost on plants}

We chose maize and wheat as our model organisms since they have been shown to have a shorter rate of germination and are important agricultural crops. The percentage germination of the plants were found to be increased considerably in maize

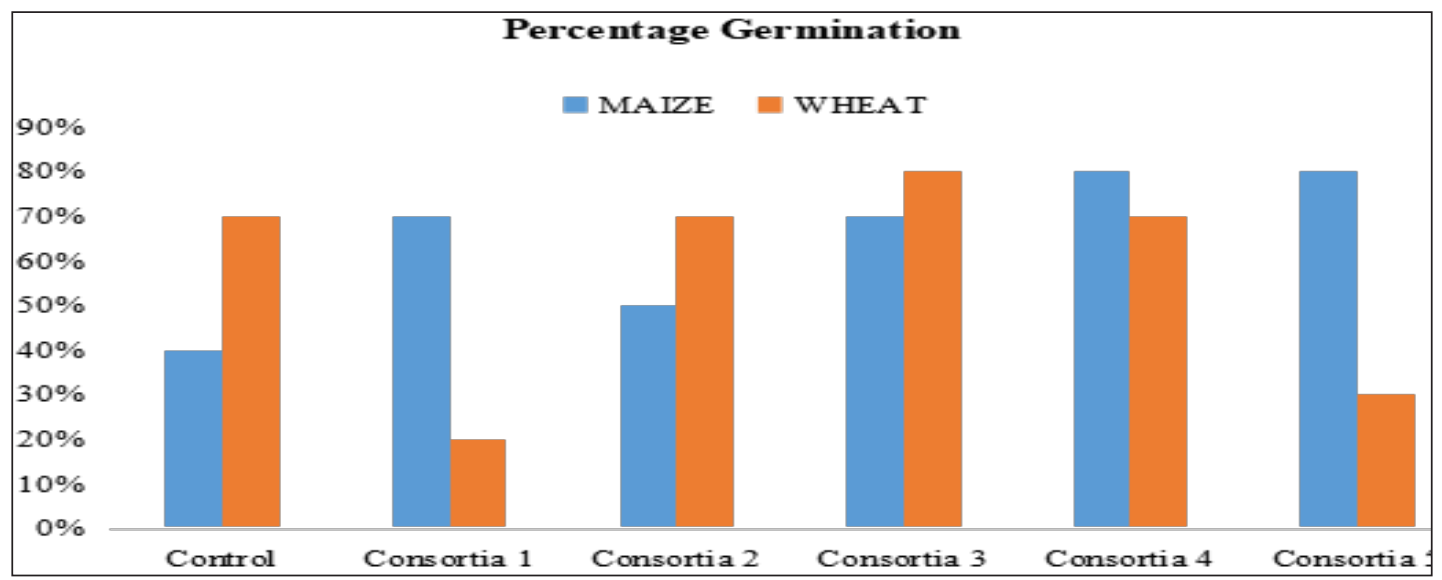

Graph 3: Effect of compost on percentage germination of maize and wheat

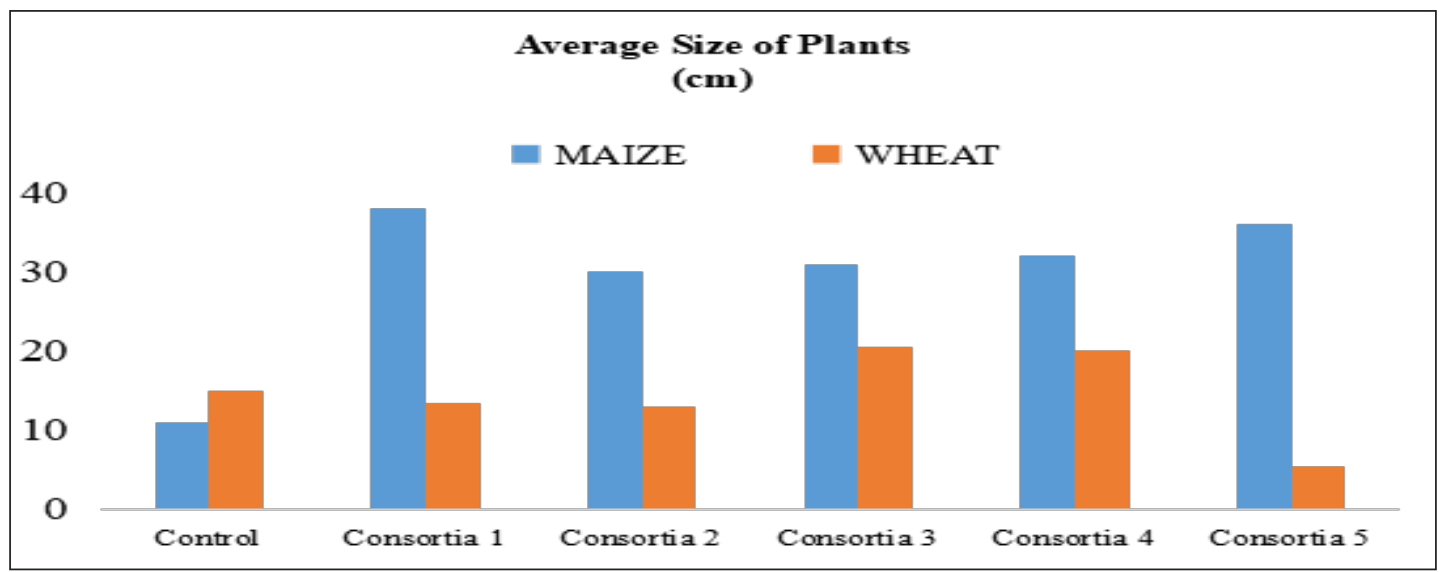

Graph 4: Effect of compost on average height (in $\mathrm{cm}$ ) of plants 


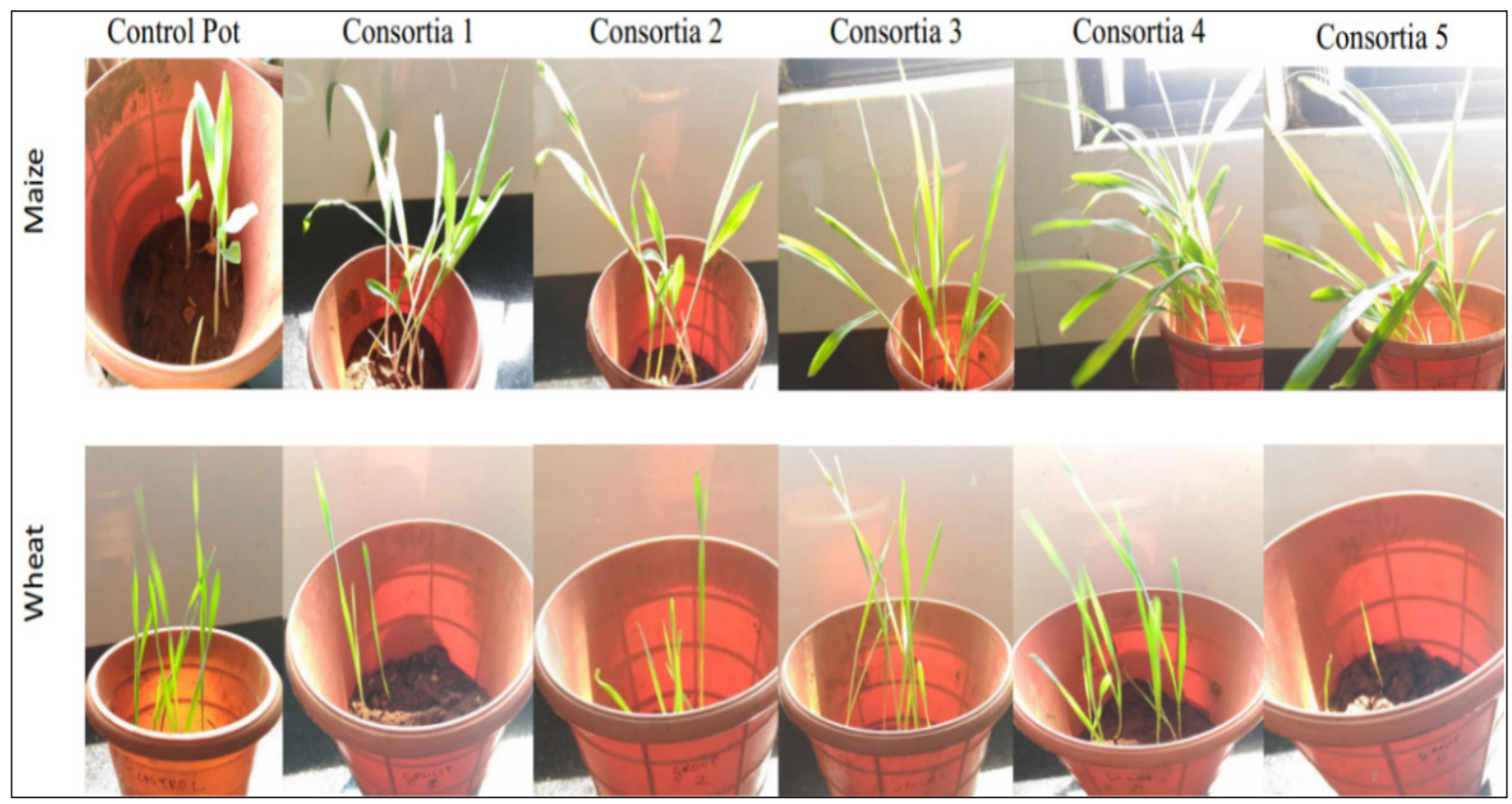

Fig. 2: Plants growing in the pots

when grown in presence of the manure degraded with different consortium, with consortium 4 and 5 giving the best germination index. However, there was no significant difference in the germination percentage of wheat when compared with the control, moreover consortia 1 and 5 showed a decrease in the germination index. After 15 days, the average height of maize and wheat were evaluated. Consortia 1 showed the best average size in comparison to Consortia 5, 4, 3, 2 considering maize and in case of wheat, Consortia 3 and 4 show better average growth followed by Control, Consortia 1, 2 and 5 (Graph 4).

\section{CONCLUSION}

The consortia were found to be effective in degradation of organic waste and the resulting compost was found to be effective in improving the soil characteristics and in the growth of plants. It can be formulated, dried and made available to farmers so that they can make use of it. It can also be used at home as the degradation of kitchen waste with the consortia does not liberate any stench.

Field study has to be conducted to check the effect on different crops. Further modification of consortia can be done to help plant uptake nutrient efficiently. Effect of consortia on wide variety of Organic Wastes has to be Studied.

\section{ACKNOWLEDGEMENTS}

We thankfully acknowledge the Management of Pillai College of Arts, Commerce and Science, Panvel, Navi Mumbai for providing the necessary infrastructure and funds. We are grateful to $\mathrm{Mr}$. Siddhant Padte for providing the samples.

\section{REFERENCES}

Gupta, S, Krishna, M., Prasad, R.K., Gupta, S. and Kansai, A. 1998. Solid Waste Management in India: Options and Oppurtunities. Resource, Conservation and Recycling, 24: $137-154$.

Horneck, D.A., Sullivan, D.M., Owen, J.S. and Hart, J.M. Soil Test Interpretation Guide. EC 1478, OSU Catalog.

Irfan, M., Safdar, A., Syed, Q. and Muhammad, N. 2012. Isolation and screening of cellulolytic bacteria from soil and optimization of cellulase production and activity. Turkish J. Biochem., 12; 37 (3): 287-293.

Joshi, R. and Ahmed, S. 2016. Status and challenges of municipal solid waste management in India: A review, Cogent Environmental Science, 2.

Kumar, S., Stephen R. Smith Geoff Fowler, Velis, C., Arya, S., Rena, Kumar, R. and Cheeseman, C. 2017. Challenges and opportunities associated with waste management in India. R. Soc. Open Sci., 4(3).

Olsen, S.R., Cole, C.V., Wantanable, F.S. and Dean, L.A. 1954. Estimation of available phosphorus in soil by extraction with Sodium bicarbonate. United State Dept. of Agric. CIRC., Washinton, D.C., 939.

Rakshit, A., Sarkar, B. and Abhilash, P.C. 2018. Soil amendments for sustainability: challenges and perspectives. CRC Press, Boca Raton, FL, USA. 


\section{?}

Rupali, D. 2015. Screening and Isolation of Protease Producing Bacteria from Soil Collected from Different Areas of Burhanpur Region (MP) India. Int. J. Curr. Microbiol. App. Sci., 4(8): 597-606.

Sarkar, P. and Chourasia, R. 2017. Bioconversion of organic solid wastes into biofortified compost using a microbial consortium. Int. J. Recycl. Org. Waste Agricult., 6: 321-334.

Sharma, A.K., Sharma, V., Saxena, J., Chandra, R., Alam, A. and Prakash, A. 2015. Isolation and Screening of Amylolytic Bacteria from Soil. Int. J. Scient. Res. Agril. Sci., 2(7): 159-165.

Singh, J.P., Kaur, A., Shevkani, K. and Singh, N. 2016. Composition, bioactive compounds and antioxidant activity of common Indian fruits and vegetables. J. Food. Sci. Technol., 53: 4056.

Song, C., Zhang, Y., Xia, X., Qi, H., Li, M., Pan, H. and Xi, B. 2018. Effect of inoculation with a microbial consortium that degrades organic acids on the composting efficiency of food waste. Microbial Biotechnology, 11: 1124-1136.

Subbiah, B. and Asija, G. 1956. A Rapid Procedure for the Estimation of Available Nitrogen in Soils. Cur. Sci., 25: 259-260.
Tankeshwar, A. 2019. Overview of Biochemical tests used to identify bacteria in Microbiology Laboratory. Microbeonline.

Types of Composting and Understanding the Process. Sustainable Management of Food. United States Environmental Protection Agency. 2017.

Veeranna, S. Hombalimath, Udapudi, B.B., Patil, L.R., Shet, A., Yaraguppi, D. and Tennalli, G. 2012. Isolation and characterization of Lipolytic microorganisms from oil contaminated soil. Int. J. Adv. Eng. Sci. Tech., 2 (3), 293-297.

Walkley, A.J. and Black, I.A. 1934. Estimation of soil organic carbon by the chromic acid titration method. Soil Sci., 37: $29-38$

Zaved, H.K., Rahman, M.M., Rahman, M.M., Rahman, A., Arafat, S.M.Y. and Rahman, M.S. 2008. Isolation and Characterization of effective bacteria for solid waste degradation for organic manure. KMITL Sci. Tech. J., 8(2): 44-55.

Ziraba, A.K., Haregu, T.N. and Mberu, B. 2016. A review and framework for understanding the potential impact of poor solid waste management on health in developing countries. Arch Pub. Heal., 74: 55. 